\title{
EKSPLORASI APLIKASI PUSH TO TALK PADA MOBILE PHONE
}

\author{
Deffy Susanti \\ Teknik Informatika, Fakultas Teknik Universitas Majalengka \\ Email : deffysusanti@gmail.com
}

\begin{abstract}
ABSTRAK
Fitur push-to-talk (PTT) adalah fitur yang memanfaatkan fasilitas pada perangkat mobile. Pada fitur ini, pengguna ponsel dapat berbicara satu arah dengan lawan berbicaranya dengan menekan satu tombol untuk memulai percakapan sehingga terbentuk paket suara yang kemudian dikirim lewat jaringan GPRS. PTT adalah fitur yang tersedia pada model telepon seluler tertentu. Maka pada mode khusus yang telah diatur sebelumnya, telepon seluler dapat berfungsi untuk berkomunikasi secara push-to-talk. Hanya satu orang yang dapat berbicara pada suatu saat, dengan menekan tombol PTT, dan orang lain dapat mendengarkan pesan yang dikirimkan secara otomatis. Layanan ini akan menghubungkan kedua pengguna telepon seluler ini dalam hitungan detik. PTT tidak menggunakan hitungan tarif airtime biasa seperti pada metode komunikasi biasa, tetapi menggunakan hitungan khusus tiap detik. Eksplorasi ini menghasilkan visualisasi dari cara kerja push to talk yang dibuat dengan menggunakan tools pemograman macromedia flash versi 8 dan sound forge yang digunakan untuk mengolah suara.
\end{abstract}

\section{Kata Kunci : PTT, GPRS, Mobile}

\section{PENDAHULUAN}

Teknologi seluler saat ini yang berkembang dengan pesat telah mengantarkan manusia untuk memanfaatkan berbagai macam fasilitas tidak hanya untuk berkomunikasi layaknya secara biasa (secara audio saja layaknya telepon rumah biasa) tetapi juga dapat dimanfaatkan untuk berbagai fasilitas multimedia. Indonesia termasuk salah satu negara yang cepat mengadopsi teknologi di bidang seluler, contohnya dalam bidang pengimplementasian fitur GPRS (General Packet Radio Service), EDGE (Enhanced Data Rates for GSM Evolution), hingga 3G (The Third Generation). Tetapi, kecepatan operator di Indonesia dalam mengadposi teknologiteknologi tersebut kurang diimbangi dengan pemanfaatannya oleh konsumen.

Salah satu layanan yang sedang dalam pengembangan operator-operator di Indonesia adalah push-to-talk yang merupakan layanan pada jaringan seluler yang menyerupai fungsi wakie-talkie. Fungsi ini sudah populer di Amerika utara. Negara-negara tetangga seperti Thailand dan Australia juga sudah lebih dulu meluncurkan teknologi ini. Cara bertelepon normal biasanya adalah full-duplex artinya kedua belah pihak (penelepon dengan penerima telepon) dapat saling mendengarkan pada saat yang bersamaan. Tetapi push-to-talk adalah half-duplex artinya komunikasi hanya bergerak satu arah pada waktu tertentu.
Melalui fitur push-to-talk ini, pengguna ponsel / perangkat mobile dapat berbicara secara cepat dengan lawan berbicaranya baik secara personal maupun dengan grup. Fitur ini dapat diaktifkan dengan menekan satu tombol untuk memulai percakapan. Selanjutnya pengguna dapat memulai berbicara hingga terdengar pada ponsel yang diaktifkan oleh lawan berbicara.

Untuk dapat memanfaatkan layanan push-totalk ini, dibutuhkan perangkat mobile khusus yang mendukung layanan ini seperti Nokia 5140 (perangkat mobile pertama yang mendukung layanan ini) dengan operator yang juga mendukung layanan ini

\subsection{Batasan Masalah}

Batasan masalah ini digunakan agar masalah yang dibahas tidak terlalu luas sehingga dapat memudahkan pekerjaan dan untuk menghindari adanya kegiatan diluar tujuan yang diharapkan. Batasannya pada eksplorasi ini yakni tidak sampai pada pembuatan perangkat lunak dan hanya eksplorasi pada telepon genggam yang menghasilkan visualisasi cara kerja push to talk.

\subsection{Landasan Teori}

a. Telepon Genggam

Telepon genggam atau lebih terkenal dengan sebutan handphone (disingkat HP; 
disebut juga sebagai telepon selular atau ponsel) adalah sebuah perangkat telekomunikasi elektronik yang mempunyai kemampuan dasar yang sama dengan telepon fixed line yang konvensional namun dapat dibawa ke mana-mana (portabel) dan tidak perlu disambungkan dengan jaringan telepon menggunakan kabel (nirkabel; wireless) (Douskalis,PH PTR) Indonesia mempunyai dua jaringan telepon nirkabel saat ini yaitu GSM (Global System For Mobile Telecommunications) dan CDMA (Code Division Multiple Access).

\section{b. Sinyal analog dan sinyal digital}

Sinyal analog adalah sinyal yang perubahannya tidak terputus terhadap waktu. Dalam transmisi analog maka akan terlihat bentuk gelombang tersebut disetiap tahap pengiriman (Hill, Mc Graw)

Sinyal digital adalah sinyal yang berbentuk pulsa - pulsa tegangan atau arus terputus putus yang menggambarkan pengkodean dari sinyal aslinya( analog atau digital ) (Hill, Mc Graw)

\section{c. Codec}

Codec adalah suatu alat atau program yang mampu melakukan penyandian dari data analog menjadi digital atau dari data digital menjadi analog. Codec adalah suatu singkatan dari : Compressor - Decompressor, Coder Decoder, atau Algoritma Compression/Decompression.

Codec sering digunakan untuk mengedit sebuah video. Suatu video ADC(analog-todigital konversi) akan merubah data tersebut dari data analog menjadi data digital, kemudian data tersebut disimpan ke dalam sebuah transmisi digital untuk diolah sesuai dengan keinginan user, baru kemudian DAC(digital-to-analog) bekerja merubah kembali data digital menjadi analog.

\section{METODE PENELITIAN}

\subsection{Pengertian Push to Talk}

Teknologi seluler saat ini yang berkembang dengan pesat telah mengantarkan manusia untuk memanfaatkan berbagai macam fasilitas tidak hanya untuk berkomunikasi layaknya secara biasa (secara audio saja layaknya telepon rumah biasa) tetapi juga dapat dimanfaatkan untuk berbagai fasilitas multimedia. Indonesia termasuk salah satu negara yang cepat mengadopsi teknologi di bidang seluler, contohnya dalam bidang pengimplementasian fitur GPRS (General Packet Radio Service), EDGE (Enhanced Data Rates for GSM Evolution), hingga 3G (The Third Generation). Tetapi, kecepatan operator di Indonesia dalam mengadposi teknologiteknologi tersebut kurang diimbangi dengan pemanfaatannya oleh konsumen.

Salah satu layanan yang sedang dalam pengembangan operator-operator di Indonesia adalah push-to-talk yang merupakan layanan pada jaringan seluler yang menyerupai fungsi wakie-talkie. Fungsi ini sudah populer di Amerika utara. Negara-negara tetangga seperti Thailand dan Australia juga sudah lebih dulu meluncurkan teknologi ini. Cara bertelepon normal biasanya adalah full-duplex artinya kedua belah pihak (penelepon dengan penerima telepon) dapat saling mendengarkan pada saat yang bersamaan. Tetapi push-to-talk adalah half-duplex artinya komunikasi hanya bergerak satu arah pada waktu tertentu.

Melalui fitur push-to-talk ini, pengguna ponsel / perangkat mobile dapat berbicara secara cepat dengan lawan berbicaranya baik secara personal maupun dengan grup. Fitur ini dapat diaktifkan dengan menekan satu tombol untuk memulai percakapan. Selanjutnya pengguna dapat memulai berbicara hingga terdengar pada ponsel yang diaktifkan oleh lawan berbicara.

Push-to-talk, atau biasa disingkat PTT, adalah sebuah metode komunikasi bertipe halfduplex dengan menekan sebuah tombol untuk memulai mengirimkan pesan yang berupa suara[ERI05]. Lalu ketika tombol tadi dilepas, suara tadi dikirimkan ke si penerima pesan. Versi PTT ini disebut dengan "Push to talk over Cellular" yang disingkat dengan "PoC".

\subsection{Prosedur pengiriman data push to talk}

Prinsip kerja dari Push to Talk yaitu kemampuan untuk menyampaikan kepada suatu kelompok atau perseorangan, sehingga siapapun dapat berbicara dan mendengar dengan jelas. Kemampuan ini juga harus didukung dengan kinerja jaringan yang optimal, sehingga pengiriman suara tidak mengalami keterlambatan.

Jaringan Push to Talk didasarkan pada $\mathrm{SIP}($ session initiation protocol) dan $\mathrm{RTP}($ Realtime protocol). 


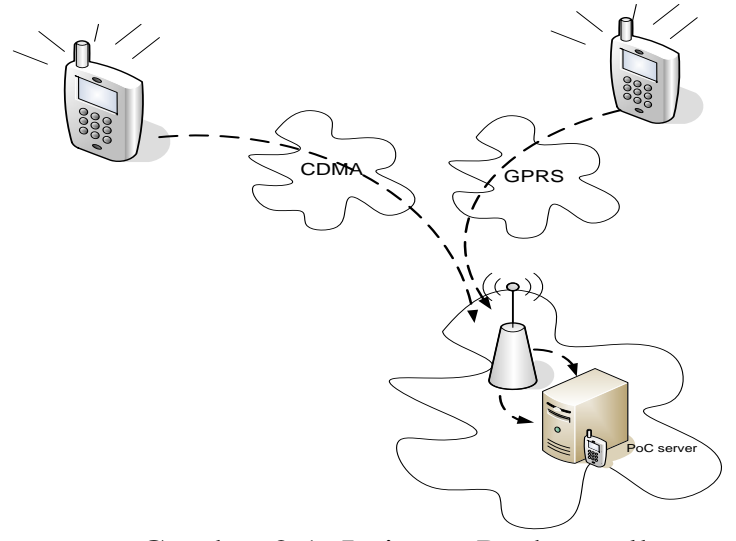

Gambar 2.1. Jaringan Push to talk

Gambar di atas merupakan jaringan push to talk. Ketika seseorang berbicara, maka file tersebut akan dikirimkan ke server push to talk melalui jaringan GPRS/CDMA, di server file tersebut akan dikirimkan ke lawan bicara dengan melalui jaringan yang sama.

Prosedur pada Push to Talk dapat dilihat pada gambar dibawah ini :

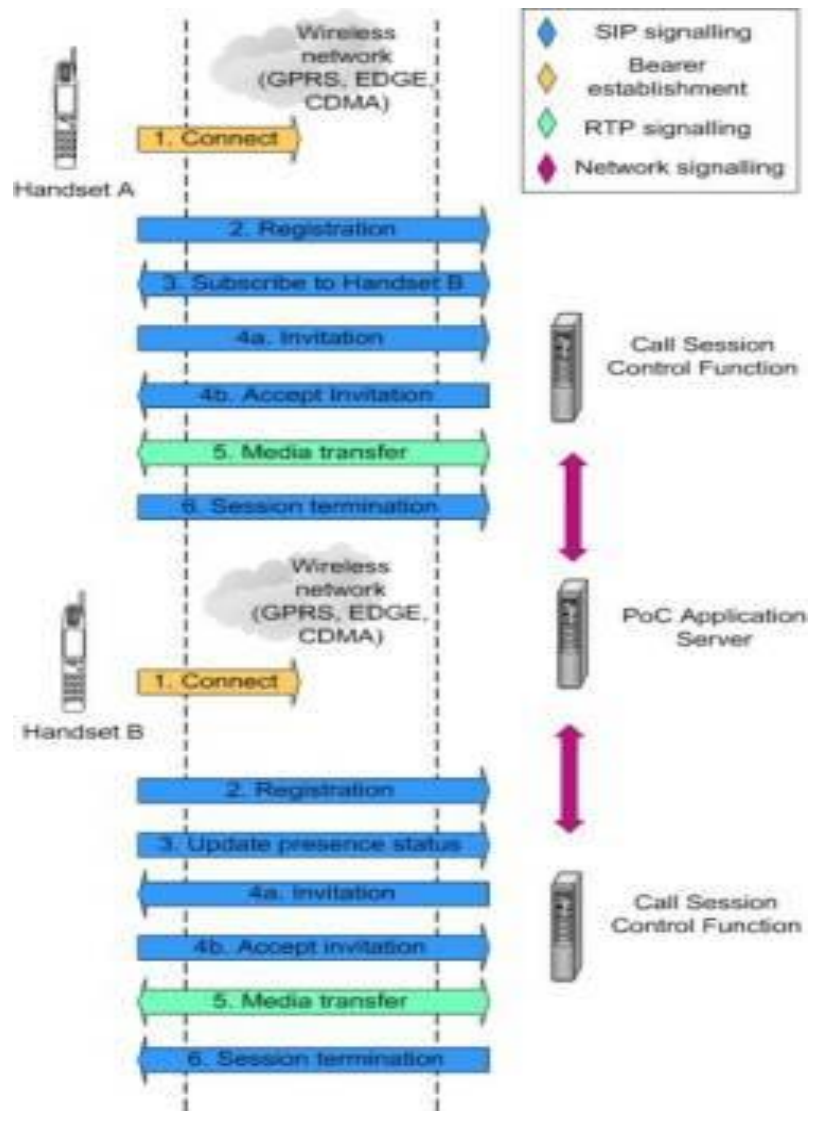

Gambar 2.2. Prosedur dalam membangun PoC hingga akhir pembicaraan.

Prosedur dalam membangun suatu $\mathrm{PoC}$ memiliki enam langkah seperti digambarkan pada gambar diatas. Enam langkah tersebut antara lain:

1) Establishment of a data bearer. Yaitu melakukan proses koneksi dengan provider yang menyediakan layanan PoC.

2) Registration. Jika belum mendaftar dengan PoC server, maka pada prosedur pendaftaran ini juga menyediakan pendaftaran secara langsung pada perangkat mobile, yaitu dengan mengirimkan IP address, kemudian prosedur ini akan mengecek keaslian dari jaringan itu.

3) Subscription. Adalah melakukan hubungan dengan orang yang dikehendaki. Permintaan ini akan menghasilkan suatu tanggapan/ konfirmasi yang berisi status diterima atau ditolak.

4) Invitation/acceptance. Adalah proses untuk memulai suatu sesi pembicaraan dengan menggunakan SIP. Prosedur ini kemudian akan dikirimkan kepada PoC server, yang kemudian akan dikirimkan ketujuan. Prosedur ini juga memeriksa semua sesi pertukaran informasi antar keduanya.

5) Media transfer. Serupa seperti buffer atau tempat sementara yang menampung suara seseorang yang kemudian akan dikirimkan kepada lawan bicaranya. PoC merupakan half duplex, maka peserta harus meminta ijin untuk mengirimkan suatu paket suara, pada saat seseorang mengirimkan paket suara maka suara tersebut disimpan dalam media transfer ini. Selama perpindahan media, mengirim dan menerima suatu data suara sangat tergantung pada kondisi jaringan .

6) Session termination. Merupakan akhir pembicaraan, ketika kedua belah pihak memutuskan untuk menghentikan pembicaraan.

Untuk dapat melakukan suatu proses $\mathrm{PoC}$, maka selain didukung oleh jaringan, $\mathrm{PoC}$ juga harus didukung oleh perangkat mobile yang menyediakan aplikasi ini.

\subsection{Penerimaan paket suara pada mobile phone}

Suatu PoC yang baik adalah diukur dari segi kecepatan dalam pengiriman paket suara. Kinerja antara SIP dan RTP pada kinerja PoC merupakan sebuah perpaduan yang sangat penting dalam sistem ini Waktu merupakan prioritas utama pada sistem PoC, sehingga kerja RTP sangat berperan penting sebagai 
pengirim data sehingga data dapat dikirim dan diterima.

Jika kita memperhitungkan hal tersebut, maka langkah yang harus diambil untuk dapat mengoptimalkan kerja PoC adalah sebagai berikut :

1) Ketika suatu paket data tiba pada mobile phone, maka pembawa paket yaitu RTP akan menyampaikan data tersebut ketempat yang sesuai di mobile phone. Data tersebut akan diterima oleh TCP/IP pada mobile phone.

2) Jika paket ditujukan untuk SIP, maka paket tersebut akan disimpan pada tumpukan SIP dan kemudian akan diproses. SIP tersebut akan menghasilkan sebuah pesan yang kemudian akan dikirimkan ke PoC client sehingga dapat didengar oleh client melalui audio.

3) Jika data ditujukan untuk RTP, maka paket data tersebut akan disimpan pada tumpukan data RTP kemudian akan dikirimkan ke PoC client.

4) Dari PoC client data tersebut akan dikirimkan kebagian codec untuk diubah kedalam bentuk analog, yang kemudian akan dikirimkan kebagian audio.

5) Ketika data dirasakan cukup untuk melakukan sebuah percakapan, maka sistem audio akan mengirimkan suara yang dapat didengar oleh client.

Proses yang terjadi berdasarkan langkah diatas dapat dilihat pada gambar 3 dibawah ini

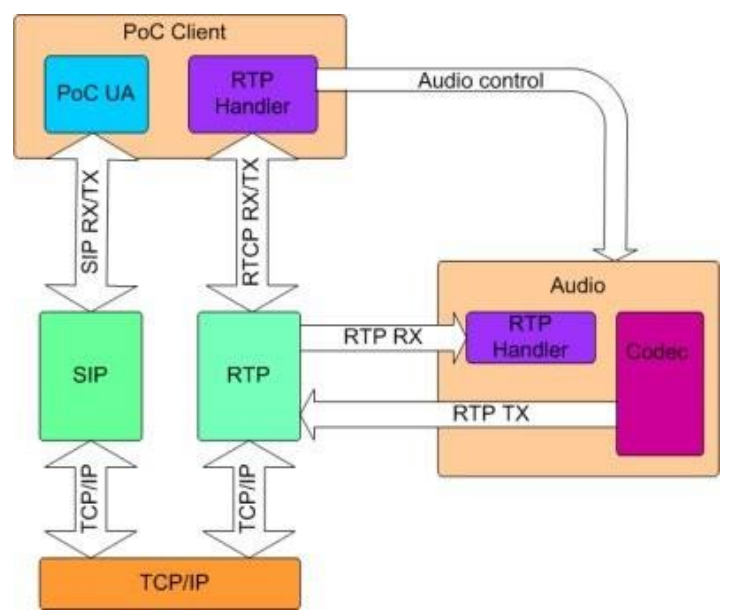

Gambar 2.3. Proses pengolahan data pada PoC

\subsection{Kesulitan pada PoC}

Kesulitan yang umumnya terjadi terjadi disisi perangkat mobile phone. Penempatan komponen - komponen yang mendukung sistem PoC merupakan salah satu kendala. Pada umumnya mobile phone dibuat untuk memenuhi kebutuhan dari prioritas masyarakat yang ada. Misalnya saja di indonesia mobile phone yang mendukung $\mathrm{PoC}$ ini jarang ditemukan karena mayoritas kebutuhan masyarat bersandar hanya sebatas MMS dan Video Streaming.

\section{HASIL DAN PEMBAHASAN}

\subsection{Contoh Cara Pemakaian Push to Talk}

Terdapat 4 tahap dalam pemakaian push to talk. Contoh yang akan penulis sajikan adalah menggunakan mobile phone Nokia seri 5140. Nokia seri 5140 merupakan seri nokia pertama yang telah memiliki menu layanan push to talk dalam aplikasi mobile phone nya. 4 tahap pemakaian push to talk ini yaitu :

\subsection{Melakukan koneksi (login)}

Untuk dapat menggunakan push to talk, diharuskan terlebih dahulu melakukan login. Caranya adalah dengan menekan menu dan mencari menu push to talk pada HP, lalu tekan select dan akan muncul beberapa menu pada menu push to talk seperti login to PTT, callback request, group list, contact list, add group, dan logout from PTT. Jika push to talk sedang aktif maka menu login to PTT berubah menjadi logout from PTT

\subsection{Membuat/menambahkan contacts pada perseorangan (one-to-one call)}

Diatas merupakan cara pemakaian push to talk tetapi apabila aplikasi push to talk telah tersedia. Apabila aplikasi belum tersedia maka user diharuskan melakukan penyetingan terlebih dahulu untuk aplikasi push to talk pada handphonenya.Penyetingan dapat dilakukan dengan menginstal sendiri ataupun melalui salah satu perusahaan handphone yang menyediakan aplikasi push to talk. Penulis mengambil contoh pada perusahaan NOKIA dengan penyetingan melalui internet. Terdapat dua macam penyetingan handphone untuk aplikasi pada handphone merk nokia, yang pertama adalah browsing setting dan order advanced setting. Untuk browsing setting, merupakan setting untuk jenis MMS, GPRS, dan voice mail. Sedangkan untuk order advancer

setting, merupakan setting untuk aplikasi Instant messaging, dan push to talk. 


\subsection{Kelebihan dan kekurangan push to talk}

Push to Talk memiliki beberapa kelebihan dan kekurangan yang antara lain :

\section{a. Kelebihan Push to Talk}

1. Kemampuan menyingkirkan peserta yang tidak diterima oleh peserta bicara dalam satu grup.

2. PTT bisa menyembunyikan nama dan status kehadiran pengguna dari peserta atau grup obrolan lainnya seperti misalnya kita temui pada Yahoo Messenger .

3. Tarifnya disesuaikan dengan tarif GPRS yang jauh lebih murah.Penulis mengambil contoh Negara Malaysia dengan provider Maxis,untuk telefon biasa biaya yang dikenakan sebesar RM0.20 dan biaya sms sebesar RM0.05 sedangkan untuk PTT sendiri dikenakan biaya login sebesar biaya sms yaitu sebesar RM0.05.

\section{b. Kekurangan Push to Talk}

POC kebanyakan hanya dapat digunakan dengan sesama pengguna yang berada dalam satu jaringan ponsel, tidak bisa lintas jaringan.

\subsection{Contoh Negara - negara beserta nama} providernya yang menyediakan PTT

Tabel 3.1 Contoh Negara-negara yang menyediakan fitur PTT

\begin{tabular}{|c|l|l|}
\hline No & Nama Negara & \multicolumn{1}{|c|}{ Nama Provider } \\
\hline 1 & Australia & Telstra PTT \\
\hline 2 & Austria & $\begin{array}{l}\text { T-Mobile Push to } \\
\text { Talk }\end{array}$ \\
\hline 3 & Argentina & Nii Holding \\
\hline 4 & Brazil & Oi PoC \\
\hline 5 & Canada & Telus Mobility \\
\hline 6 & Finland & Saunalahti \\
\hline 7 & Germany & XPress \\
\hline 8 & Hongkong & $\begin{array}{l}\text { New World } \\
\text { Mobility }\end{array}$ \\
\hline 9 & Israel & MiRS \\
\hline 10 & Italy & TIM \\
\hline 11 & Malaysia & $\begin{array}{l}\text { Maxis } \\
\text { Communication }\end{array}$ \\
\hline 12 & New Zealand & Boost Mobile \\
\hline 13 & Saudi Arabia & Bravo \\
\hline 14 & Thailand & AIS Push to Talk \\
\hline 15 & U.S & $\begin{array}{l}\text { Cinguar/At \& T } \\
\text { Wireless }\end{array}$ \\
\hline 16 & Ukraine & Life $:-$ Life $:$ \\
\hline 17 & Paraguay & Personal \\
\hline
\end{tabular}

\subsection{Kesimpulan Eksplorasi}

Kesimpulan eksplorasi ini berisikan kesimpulan, yang penulis peroleh dari hasil eksplorasi mulai dari prosedur pengiriman file suara, penerimaan paket suara pada mobile phone, cara pemakaian push to talk, dan cara pensetingan push to talk.

Tabel 3.2 Kesimpulan Eksplorasi

\begin{tabular}{|c|c|c|}
\hline No & Item & Hasil Eksplorasi \\
\hline 1 & $\begin{array}{l}\text { Prosedur } \\
\text { pengiriman file } \\
\text { suara }\end{array}$ & $\begin{array}{l}\text { Bila diimbangi } \\
\text { dengan kondisi } \\
\text { jaringan yang cepat, } \\
\text { maka pengiriman } \\
\text { file suara ke tujuan } \\
\text { pasti cepat dan } \\
\text { tidak terputus- } \\
\text { putus, sehingga } \\
\text { kinerja dari } \\
\text { prosedur } \\
\text { pengiriman file } \\
\text { suara lebih tinggi. }\end{array}$ \\
\hline 2 & $\begin{array}{l}\text { Penerimaan paket } \\
\text { suara pada } \\
\text { mobile phone }\end{array}$ & $\begin{array}{l}\text { Walaupun } \\
\text { handphone } \\
\text { dilengkapi dengan } \\
\text { fasilitas PTT, tapi } \\
\text { tentu saja kondisi } \\
\text { jaringanlah yang } \\
\text { menentukan cepat } \\
\text { atau lambatnya file } \\
\text { suara diterima. } \\
\text { Tetapi pemisahan } \\
\text { pada bagian RTP } \\
\text { dan SIP merupakan } \\
\text { proses yang sangat } \\
\text { sulit pada proses } \\
\text { pengolahan data di } \\
\text { PoC client. } \\
\text { Pemisahan harus } \\
\text { dilakukan dengan } \\
\text { hati-hati untuk } \\
\text { menghasilkan hasil } \\
\text { yang optimal. } \\
\text { Namun beberapa } \\
\text { kemungkinan dapat } \\
\text { dilakukan untuk } \\
\text { dapat } \\
\text { mengoptimalkan } \\
\text { kerja PoC, misalnya } \\
\text { penggunaan } \\
\text { memori dan } \\
\text { perawatan pada } \\
\text { handphone. }\end{array}$ \\
\hline
\end{tabular}




\begin{tabular}{|c|c|c|}
\hline 3 & $\begin{array}{l}\text { Cara pemakaian } \\
\text { push to talk }\end{array}$ & $\begin{array}{l}\text { Cenderung mudah, } \\
\text { dikarenakan kita } \\
\text { tinggal login lalu } \\
\text { menghubungi } \\
\text { seseorang yang } \\
\text { ingin kita ajak } \\
\text { untuk ber-PTT } \\
\text { kemudian tinggal } \\
\text { tekan tombol PTT } \\
\text { dan bebicara. } \\
\text { Tetapi tentunya } \\
\text { seseorang yang } \\
\text { diajak, juga } \\
\text { diharuskan login } \\
\text { terlebih dahulu. }\end{array}$ \\
\hline 4 & $\begin{array}{l}\text { Setting Push to } \\
\text { talk }\end{array}$ & $\begin{array}{l}\text { Penyetingan push } \\
\text { to talk cenderung } \\
\text { mudah, apalagi jika } \\
\text { handphone kita } \\
\text { sudah didukung } \\
\text { dengan fasilitas ini. } \\
\text { Kita tinggal } \\
\text { menseting nama } \\
\text { provider, kemudian } \\
\text { IP address provider } \\
\text { yang kita gunakan. } \\
\text { Apabila dalam } \\
\text { handphone kita } \\
\text { belum terdapat } \\
\text { fasilitas ini maka } \\
\text { kita tinggal } \\
\text { mensetingnya } \\
\text { melalui internet, } \\
\text { diinternet akan } \\
\text { ditanyakan jenis } \\
\text { handphone yang } \\
\text { kita miliki serta } \\
\text { negara dimana kita } \\
\text { berada, lalu tinggal } \\
\text { mengikuti langkah- } \\
\text { langkah yang } \\
\text { terdapat } \\
\text { didalamnya. }\end{array}$ \\
\hline
\end{tabular}

\section{KESIMPULAN DAN SARAN}

Kesimpulan dan saran, berisikan mengenai kesimpulan dari kegiatan Penelitian dan saran yang berkaitan dengan hasil pengerjaan Penelitian ini.

\subsection{Kesimpulan}

Kesimpulan yang dapat diambil dari pengerjaan penelitian ini adalah sebagai berikut :
1. Kelebihan dari PTT adalah kemampuan PTT yang bisa menyembunyikan nama dan status kehadiran pengguna dari peserta atau grup obrolan lain, dan kemampuan untuk memblokir peserta yang tidak diterima oleh peserta bicara pada satu grup.

2. Untuk memulai suatu percakapan seseorang diharuskan login terlebih dahulu, pesan login tersebut akan disampaikan ke PTT server yang secara otomatis akan merubah status dari tidak login menjadi login.

3. Ketika suatu paket data tiba pada mobile phone maka pertama kali akan diterima oleh TCP/IP yang kemudian akan dikirimkan ke bagian PoC client untuk memisahkan antara SIP dan RTP baru kemudian ke codec untuk diubah kedalam bentuk analog sehingga dapat didengar oleh manusia.

4. Biaya untuk PTT cenderung lebih murah bila dibandingkan dengan sms ataupun telefon. Misalnya di Malaysia harga PTT untuk sehari penuh adalah sebesar RM1 dengan biaya login sama dengan harga sms, tetapi memberikan kebebasan kepada pemakai PTT untuk berbicara selama yang diinginkan.

5. Belum diterapkan di Indonesia karena masih terbentur pada berapa besar tarif yang mau dikenakan kepada pelanggan dan dianggap akan menurunkan pendapatan average rate per user (ARPU) operator.

\subsection{Saran}

Saran - saran ini dibuat berdasarkan kesimpulan yang diperoleh yaitu sebagai berikut :

1. Provider di Indonesia hendaknya memperkenalkan aplikasi Push to Talk ini kepada masyarakat, melihat harga yang dikenakan murah untuk PTT.

2. Apabila layanan ini telah tersedia hendaknya pergunakanlah layanan ini, karena layanan ini sangat bermanfaat, misalnya saja dari segi waktu seseorang dapat berbicara sampai dengan 5 orang secara bersamaan.

3. Eksplorasi yang saya buat ini bersifat terbuka yaitu memungkinkan untuk dikembangkan oleh siapapun sehingga akan menghasilkan perangkat lunak PTT ataupun visualisasi yang dilengkapi 
dengan setting PTT baik secara online maupun setting melalui ponsel.

\section{REFERENSI}

Basalamah, Affan, " Ber-HT di Ponsel ", 2006, www.republika.co.id

Belia, syauqy, "Break-Break-an Make HP", 2006, www.pikiran-rakyat.com

Douskalis,PH PTR, Bill , " Putting VoIP to work Softswitch Network Design and Testing", Agustus 2006, www.wikipedia.com

Eriksson, Håkan, " Fujitsu Develops Push-toTalk Ubiquitous-Networking Transceiver Technology", Sept 2005,www. fujitsu.com

Hill, Mc Graw," Softswitch, Architecture for VoIP", February 24,2005,www. citforum.ru

Needham, MA , Kendrick St," Using Your mobile phone as Walky Talky", 2004,www. Partner.plusgsm

Williams,Ray," Push to Talk takes the wireless voice market",December 2005, www.comsdesign.com 